\title{
Competitor Accounting (CA) of Joint Venture Banks
}

\author{
Prakash Pokharel ${ }^{1}$
}

\begin{abstract}
In order to facilitate the collection and analysis of accounting information related with the competitor in the context of strategic management accounting, the term competitor accounting has been developed. However, no empirical results are available as to the extent to which such information influences strategic decision behavior. Main purpose of this study is to explore the effect of competitor accounting on performance of the joint venture banks, and compare the effectiveness of competitor accounting between those banks. For this structured questionnaire survey with 133 staffs of the concerned banks as well as unstructured interview with 4 senior managers were conducted. Various published and unpublished reports like annual reports of the concerned banks were also used. From the study it is found out that levels of CA formalised application appear limited, especially when compared with a widely held managerial perception that significant benefits could derive from $C A$. The CA practices noted were conducted in an unstructured and ad hoc manner. $C A$ does not have any effect on performance of Nepalese joint venture banks because of not applying any formalised CA application.

The study had/some of the limitations generally associated with a qualitative as well as quantitative study. These limitations include the degree of subjectivity that is invoked when researchers interpret qualitative data, scarcity of various resources, and accuracy of secondary data.

The study clarifies the notion of CA and provides an outline of CA management issues arising in the context of a joint venture banks. An outline is provided of those parts of a bank operation that are most likely to be more active in $C A$, together with empirically informed suggestions with respect to CA uses in a joint venture banks.
\end{abstract}

Key Words : Competitor Accounting, Strategic Management, Joint Venture Bank, Performance, Effectiveness

1 Mr. Pokharel is a Lecturer of Management at Koteshwor Multiple Campus, Koteshwor, Kathmandu affiliated to TU. Currently he is the Head of Research Management Cell of this Campus. He is the Ph.D. scholar at FOM, TU. 


\section{Introduction}

Competitor accounting began to develop in the 1980s after the development of Strategic Management Accounting (SMA). It is an important accounting tool of strategic management accounting. Therefore, it is considerably more sophisticated than traditional management accounting method (Langfieldsmith, 2008). Traditionally, management accounting has concentrated on analyzing the internal cost structure of the organization and then planning how the cost structure will change in the future so that a long term and short term plan can be developed. Now a days, use of competitor accounting is very common in many firms, although other strategic management accounting sub regions is still low (Guilding et al., 2000)

Competitor accounting is regarded as an independent topic within the field of strategic management accounting (Jarvenpaa, 1998, p. 6). Competitor accounting is the analysis of accounting information relating to competitors.

Competitor accounting understands and predicts the rivalry between firms in their quest for a competitive position in an industry (Porter, 1980). Kotler (1988) suggested that a critical benefit of competitor accounting was its capacity to pinpoint which competitors and organization could (or should) compete with, and which should be avoided. Heinen \& Hoffjan (2005) describe the various methods of competitor accounting. As per them Competitor cost assessment, Competitive position monitoring, Competitor performance evaluation are the main methods of competitor accounting.

In general, three basic perspectives of strategic management accounting can be distinguished: (1) the environmental or marketing orientation, (2) the focus on competitors and (3) the long-term, future-related orientation.

The Kosovo Competition Authority (2011) conducted the research on "Analysis of monitoring the competition in the Banking Sector in Kosovo" with the aim to assess the competition level, identification of problems or areas where the free and effective competition can be obstructed which is by all means for the well-being of the bank clients, commercial banks and the economy in general. This study analyzes several qualitative and quantitative elements that influence or determine the competition level such as: the structure of the market and its concentration, the consumers' behavior and their access to the system, the behavior of the banks toward the price. 
Nicholas Murithi Ndwiga (2011) in his study- the role of management accounting in creating and sustaining competitive advantage: A case study of equity bank, Kenya depicts that Current management accounting techniques have not been widely accepted as a means to develop a competitive advantage. The information obtained from the literature reviewed and the results from an empirical study that involved a sample of forty respondents from Equity Bank found that the modern management accounting position provide very important skills and techniques in building competitiveness.

Dr. Nachiket M. Vechalekar (2010) in his study it is clear that Strategic Management Accounting Techniques help a firm to obtain sustainable competitive advantage. The focus here is not only on cost containment or reduction but also on Cost Management, which helps a firm to achieve competitive advantage. However, an interesting question remains to be answered and that is how many firms actually use these techniques? An interesting survey was conducted of 192 companies in the manufacturing sector from the Mumbai Pune industrial belt about the strategic management accounting position followed by them.

Thapa (2010) in his study examined the strategy performance relationship in the Nepalese banks. He found that there exists a positive relationship between competitive strategies pursued by the banks and their organizational performance. The highest performance seemed to be correlated with cost prices strategy followed by differentiation strategy and focus strategy respectively. He further observed that banks have preferred more to pursue the combination of cost leadership and differentiation strategies than the market focus strategy to attain their higher performance.

R. K. Kayastha (2010) examined the strategic competitive position of the Nepalese banking industry using survey technique in Kathmandu Valley. The total seventy questionnaires were collected from the concerned bank for primary data collection. In his study he found that most of the banks have given emphasis to the nationwide branch networking and reliability/safety position, less important to the position of extra service and the staffs' advantage position respectively. It stated that the number of branches of the banks will increase throughout the nation. Similarly, the Nepalese commercial banks needed to assure their customers regarding the greater safe banking position.

In this research a set of questionnaire was developed to get a concrete and objective picture of the way how the position of the competitor accounting actually has been evolving in Joint Venture Banks in relation to the multi branch organization. Thus this is the first theme of this research. 
Sharlene Anderson, Chris Guilding, (2006) in their study explores the nature and potential of competitor-focused accounting practice (CFA) in a large hotel. For this they use unstructured tape-recorded interviews ranging from one to one-and-ahalf hours' duration were conducted with 21 senior managers representing finance, marketing, hotel operations, casino, and human resource management in a large hotel. From this study they find that levels of CFA formalised application appear limited, especially when compared with a widely held managerial perception that significant benefits could derive from applying CFA. The CFA position noted were conducted in an unstructured and ad hoc manner. The main generic use of CFA is in connection with sensitising staff with respect to competitors' strengths and also strategy development. The hotel shared occupancy level information with competing hotels.

Christoph Heinen and Andreas Hoffjan (2005) in their study of the strategic relevance of competitor cost assessment - an empirical study of competitor accounting states that the objective of the study is to examine the potential influence of the relative cost position on strategic decisions and to investigate a possible connection between knowledge of competitor-related costs and the success of one's own company. In order to design the experiment as realistically as possible, the business game MARGA is used. Effectiveness of a central instrument of competitor accounting, the assessment of the competitor's cost, is examined in a laboratory experiment. The results reveal that cost leaders who are aware of their cost lead, act differently than cost leaders without such knowledge. Informed cost leaders implement their strategic decisions much more resolutely.

Competitor accounting - the use and methods of Porter (Michael Porter) in the famous "competitive advantage" in his book pointed out: the fierce competition among the existing competitors, the extent affecting the industry, an important force in the profitability of one, usually by the various factors.

According to discussion with the executives and other officer level staffs the second theme was developed. For that purpose comparison with similar organization in the same territory especially different joint venture banks have been done. Generally banks are competing in terms of product they introduce to the customer. It might be in terms of deposit or in terms of loans and advances. Main determinant factor of those products is interest rate and the customers are also attracted towards their product based on interest rate and scheme they provide. 
Competitor accounting practice and method are very limitedly applied by any business firm for the purpose of effective competitor analysis. In this connection joint venture banks are also facing cut throat competition from its competitor such as competition between and among Standard Chartered Bank, Everest Bank, Nabil Bank and Himalayan Bank in terms of collecting deposit from customer as well as providing loans \& advances to the customer on different interest rates through different schemes.

Within the context of above theme three specific objectives have been pursued:

1. To examine the closest competitor of Standard Chartered Bank Ltd., Himalayan Bank Ltd., Nabil Bank Ltd. and Everest Bank Ltd.

2. To analyse the financial competitive position of those banks with the closest competitor.

3. To evaluate interdependency between competitor accounting and relative performance.

The study is significant from three points of view. First, by describing current position in setting up competitor accounting systems, the state-of-the-art in this field of strategic analysis is profiled. Thus, managers of companies that already have competitor accounting systems can benchmark their systems with those described in the study and make improvements, if necessary. Secondly, the study should help companies that do not have a system for collecting competitor information to establish one. Thirdly this study also try to compare the joint venture bank in terms of competitor accounting position from which they can find out themselves that whether they are following good competitor analysis system or not.

\section{Research Method}

This study is more analytical and empirical. The study is based on analytical, descriptive and exploratory research design. It covers quantitative methodology using financial and statistical tools. The study is simultaneously based on primary data through questionnaire survey and secondary data gathering from respective annual reports of concerned banks especially from profit and loss account, balance sheet and other publication.

Among 32 commercial and seven joint venture banks only four joint venture banks are taken as a sample for comparative study. They are:

1. Standard Chartered Bank Nepal Ltd.

3. Himalayan Bank Ltd.
2. Nabil Bank Ltd.

4. Everest Bank Ltd. 
All primary data are collected by the researcher for the purpose of statistical analysis through distributing the questionnaire to the company staffs both officer as well as nonofficer level of concerned banks in Kathmandu valley only.

The secondary sources of data collections are those that have been used from published on used by someone previously. The annual reports of the concerned banks are the major sources of data for the study. Besides the annual reports of the subjected banks, some supplementary data and information have been collected from the authoritative sources like Nepal Rastra Bank, Central Library of T.U., Security Exchange Board, Economic Survey, different journals, magazines, websites, booklets and other published and unpublished reports documented by the authorities.

From the study of all the available sources researcher developed some dependent and independent research variable with regards to competitor accounting. Out of them independent research variable are given below:

\begin{tabular}{|c|c|c|}
\hline Competitor Analysis & $\begin{array}{l}\text { Porter's Five } \\
\text { Forces Model }\end{array}$ & Internal Analysis \\
\hline $\begin{array}{l}\text { Competitor Array } \\
\text { Defining own industry's } \\
\text { nature and scope } \\
\text { Determining competitors } \\
\text { Determining customers } \\
\text { Determining Key Success } \\
\text { factors } \\
\text { Competitor Profiling } \\
\text { Financial Result } \\
\text { Marketing Activities } \\
\text { Product Analysis } \\
\text { Strengths \& Weakness } \\
\text { Organizational Policies } \\
\text { New Competitor } \\
\text { Related Product } \\
\text { Related Market } \\
\text { Related Technologies }\end{array}$ & $\begin{array}{l}\text { - Threats of New } \\
\text { Entrants } \\
\text { - Bargaining Power } \\
\text { of Supplier } \\
\text { - Bargaining Power } \\
\text { of Buyers } \\
\text { - Threats of } \\
\text { Substitute } \\
\text { Products } \\
\text { Intensity of } \\
\text { Rivalry }\end{array}$ & $\begin{array}{l}\text { - Threats of New Entrants } \\
\text { Bupplier } \\
\text { - Bargaining Power of Buyers } \\
\text { - Threats of Substitute } \\
\text { Products } \\
\text { - Intensity of Rivalry }\end{array}$ \\
\hline
\end{tabular}


Likewise dependent research variable are: Return on Assets (ROA)\&Return on Equity (ROE).

\section{Development of Hypothesis}

Competitor Analysis with Performance of Joint Venture Banks:

Null Hypothesis $\left(\mathbf{H}_{\mathbf{0}}\right)$ : there is no significant effect of competitor analysis with performance of joint venture banks.

Alternative Hypothesis $\left(\mathbf{H}_{1}\right)$ : there is significant effect of competitor analysis with performance of joint venture banks.

Components of Porter's Five Forces Model with Performance of Joint Venture Banks:

Null Hypothesis $\left(\mathbf{H}_{\mathbf{0}}\right)$ : there is no significant effect of components of Porter's Five Forces Model with performance of joint venture banks.

Alternative Hypothesis $\left(\mathbf{H}_{1}\right)$ : there is significant effect of components of Porter's Five Forces Model with performance of joint venture banks.

Internal Analysis with Performance of Joint Venture Banks:

Null Hypothesis $\left(\mathbf{H}_{\mathbf{0}}\right)$ : there is no significant effect of internal analysis with performance of joint venture banks.

Alternative Hypothesis $\left(\mathbf{H}_{\mathbf{1}}\right)$ : there is significant effect of internal analysis with performance of joint venture banks.

Competitor Accounting Position with Performance of Joint Venture Banks:

Null Hypothesis $\left(\mathbf{H}_{\mathbf{0}}\right)$ : there is no significant effect of competitor accounting position withperformance of joint venture banks.

Alternative Hypothesis $\left(\mathbf{H}_{1}\right)$ : there is significant effect of competitor accounting position with performance of joint venture banks

All primary and secondary data are processed through SPSS software for analysis purpose. Descriptive analysis, cluster analysis, correlation analysis, regression analysis was used as statistical tools and ROA \& ROE was used as financial tools for analysis purpose. 


\section{Findings of the study}

\section{Denftogram Using Average Linkage (Between Groups)}

\section{Rescaled Distance Cluster Combine}

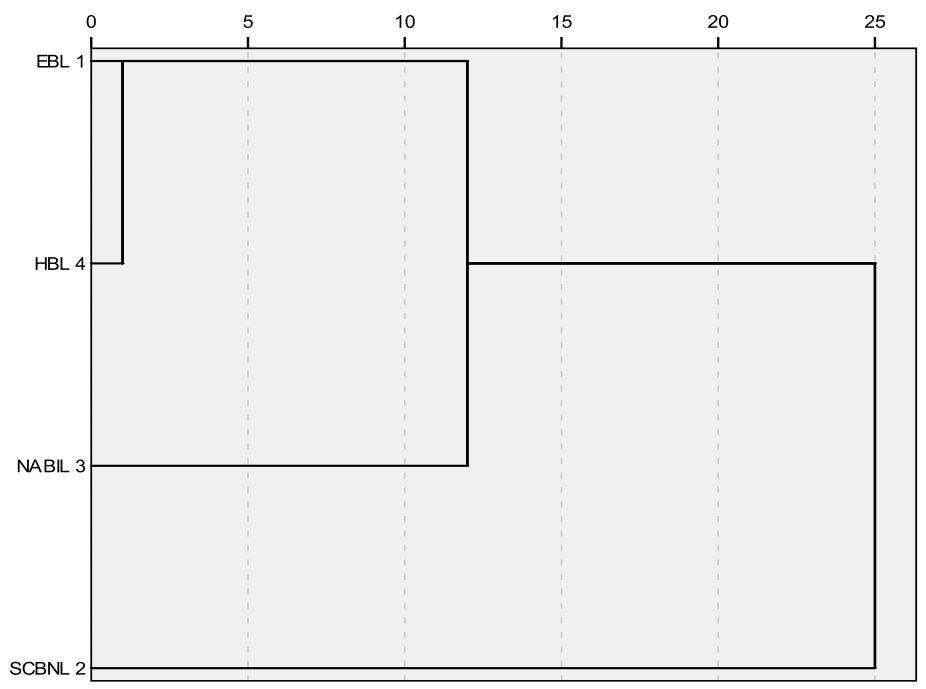

Above Cluster analysis clearly shows that there are two clusters. In one clusters there are three banks viz. EBL, HBL \& NABIL and in another clusters there is only one banks viz. SCBNL. This means EBL, HBL \& NABIL are the close competitors where as SCBNL cannot be treated as close competitors of other concerned banks.

Table 1: Demographic characteristics of Respondents

\begin{tabular}{|c|c|c|c|c|}
\hline Characteristics & Categories & Frequency & Percentage & Cumulative (\%) \\
\hline \multirow{4}{*}{ Age Group } & $<25$ years & 16 & 12 & 12 \\
\cline { 2 - 5 } & $25-35$ years & 103 & 77 & 89 \\
\cline { 2 - 5 } & $>35$ years & 14 & 11 & 100 \\
\hline \multirow{3}{*}{ Gender } & Male & 89 & 67 & 67 \\
\cline { 2 - 5 } & Female & 44 & 33 & 100 \\
\hline \multirow{3}{*}{ Qualification } & Master & 86 & 65 & 65 \\
\cline { 2 - 5 } & Bachelor & 38 & 28 & 93 \\
\cline { 2 - 5 } & Other & 9 & 7 & 100 \\
\hline \multirow{3}{*}{ Designation } & Officer & 85 & 64 & 64 \\
\cline { 2 - 5 } & Non-officer & 48 & 36 & 100 \\
\hline
\end{tabular}


From the above table 1, we can say that most of the respondents are from the age group of 25-35 years. $67 \%$ of the respondents are male respondents and $65 \%$ have post graduate qualification. $64 \%$ of the respondents are officer level staff.

Table 2: Competitive Profile Analysis

\begin{tabular}{|l|c|c|c|c|}
\hline \multicolumn{1}{|c|}{ Characteristics } & Categories & Frequency & Percentage & Cumulative (\%) \\
\hline \multirow{3}{*}{ No. of Close Competitors } & $<5$ Years & 66 & 50 & 50 \\
\cline { 2 - 5 } & $5-10$ Years & 53 & 40 & 90 \\
\cline { 2 - 5 } & $>10$ Years & 14 & 10 & 100 \\
\hline \multirow{2}{*}{$\begin{array}{l}\text { Prediction of Competitor's } \\
\text { Future Moves }\end{array}$} & Yes & 82 & 62 & 62 \\
\cline { 2 - 5 } & No & 51 & 38 & 100 \\
\hline \multirow{2}{*}{ Future of Banking Business } & Good & 125 & 94 & 94 \\
\cline { 2 - 5 } & Bad & 8 & 6 & 100 \\
\hline \multirow{2}{*}{ Nature of Competitors } & Similar & 116 & 87 & 87 \\
\cline { 2 - 5 } & Diverse & 17 & 13 & 100 \\
\hline Product Introduce Recently & Yes & 117 & 88 & 88 \\
\cline { 2 - 5 } & No & 16 & 12 & 100 \\
\hline
\end{tabular}

According table 2, most of the respondents argue that there are less than five close competitors with which concerned banks should compete. It is also found out that concerned four banks are leading banks of Nepal and they are competing with each other.

Almost all respondents argue that banks are providing unique and different services to the customer than other in spite of having similar nature of competition between them.

Most of the banks have six to eight group of deposit product where as eight to twelve group of loan product. Except SCBNL all other concerned banks have introduced either deposit or loan product recently. SCBNL has lowest interest rate on deposit product than other competitors and it is making more return from interest rate variation between deposit and loan.

From above analysis it can be said that there is cut throat competition between EBL, NABIL and HBL but somewhat the competition between SCBNL and other three banks is different than the competition between other three. SCBNL is not trying to increase normal customer for collecting deposits. 
Table 3: Performance Analysis of Four Joint Venture Banks (On the Basis of Five Years Average) (Rs. In Millions)

\begin{tabular}{|l|c|c|c|c|}
\hline \multicolumn{1}{|c|}{ Particulars } & SCBNL & NABIL & EBL & HBL \\
\hline Net Profit & 1043.6 & 1196.1 & 788.7 & 749.8 \\
\hline Total Assets & 39924.7 & 50898.7 & 41956.9 & 43864.7 \\
\hline Total Deposits & 34848.5 & 44078.8 & 37073.1 & 38557.5 \\
\hline Loans \& Advances & 16271.7 & 32172.8 & 27948.2 & 27760.7 \\
\hline Share Holders Equity & 3343 & 3886.3 & 2954.4 & 3539.9 \\
\hline No. of Branches(Nos.) & 18 & 38 & 37 & 22 \\
\hline Dividend Payout Ratio (\%) & 82 & 69 & 52.6 & 37.1 \\
\hline ROE (\%) & 31.468 & 30.54 & 27.072 & 21.454 \\
\hline ROA (\%) & 2.614 & 2.5 & 1.85 & \\
\hline
\end{tabular}

As per table 3, Net profit of every bank is increasing year by year but rate of five year's average growth is highest in EBL i.e. $25.21 \%$ followed by NABIL $22.46 \%$ whereas five year's average in rupees is highest for NABIL i.e. Rs. 1196.1 million followed by SCBNL with Rs. 1043.6 million. NABIL is earning more profit than other in this study period.

Total assets of every bank is increasing year by year but rate of five year's average growth is highest in EBL i.e. 19.58\% followed by NABIL 14.30\% whereas five year's average in rupees is highest for NABIL i.e. Rs. 50898.7 million followed by HBL with Rs. 43864.7 million. NABIL has more total assets than other in this study period.

Main indicator of performance is ROA which is also increasing year by year for all the concerned banks. Average five year's growth rate is highest in HBL with 5.87\% followed by NABIL $5.50 \%$ but in terms of five year's average SCBNL has highest ROA followed by NABIL.

Another main indicator of performance is ROE which is fluctuating year by year for all the concerned banks. Average five year's growth rate is highest in NABIL with $1.23 \%$ and lowest in SCBNL which is $-3.55 \%$ but in terms of five year's average SCBNL has highest ROE followed by NABIL.

In terms of performance NABIL has competitive advantage over other because it has more profit, more assets, more shareholders equity, more deposits as well as loans and advances than other competitor banks. It has also more number of branches than others. 
Almost all financial parameters of SCBNL are constant which shows that it is less risky for shareholders as well as other concerned parties. It has big competitive advantage of low cost deposits which is big threats for other competitor banks. With small transactions also it can earn more profit. It's almost deposits comes from NGOs and INGOs having low interest cost.

SCBNL is also distributing high rate of dividend to its shareholders as well as high payment to its staff which also increase the retaining power of banks in terms of staff and satisfied shareholders.

Table 4: Hypothesis Testing (Regression Analysis)

\begin{tabular}{|c|l|l|l|l|}
\hline & \multicolumn{1}{|c|}{ Equation } & \multicolumn{1}{c|}{$\mathbf{R}^{2}$} & \multicolumn{1}{c|}{ P-Value } & \multicolumn{1}{c|}{ Decision } \\
\hline \multirow{3}{*}{ Hypothesis I } & $\mathrm{ROA}=9.353-0.257 \mathrm{X}$ & 0.589 & 0.232 & Rejection \\
\cline { 2 - 5 } & $\mathrm{ROE}=118.82-3.706 \mathrm{X}$ & 0.713 & 0.156 & Rejection \\
\hline \multirow{3}{*}{ Hypothesis II } & $\mathrm{ROA}=1.112+0.024 \mathrm{X}$ & 0.249 & 0.501 & Rejection \\
\cline { 2 - 5 } & $\mathrm{ROE}=-7.768+0.458 \mathrm{X}$ & 0.533 & 0.270 & Rejection \\
\hline \multirow{3}{*}{ Hypothesis III } & $\mathrm{ROA}=-3.594+0.122 \mathrm{X}$ & 0.333 & 0.423 & Rejection \\
\cline { 2 - 5 } & $\mathrm{ROE}=-79.420+1.978 \mathrm{X}$ & 0.508 & 0.287 & Rejection \\
\hline \multirow{3}{*}{ Hypothesis IV } & $\mathrm{ROA}=-0.296+0.021 \mathrm{X}$ & 0.226 & 0.525 & Rejection \\
\cline { 2 - 5 } & $\mathrm{ROE}=-35.630+0.405 \mathrm{X}$ & 0.497 & 0.295 & Rejection \\
\hline
\end{tabular}

As per table 4, from the test of hypothesis (through regression analysis) it can be concluded that there is no significant effect of every variable of competitor accounting with performance of Nepalese joint venture banks.

From the above regression analysis it is find out that Nepalese joint venture banks have not applying competitor accounting in their organisation effectively. They even do not know about the competitor accounting. They only analyse the competitor in terms of profit they earn and their total assets, deposits, etc...

According to theory of competitor accounting relative performance of joint venture banks largely depends on the component of competitor accounting. But from the above analysis wecan say that relative performance of Nepalese joint venture banks will not depend on component of competitor accounting. 


\section{Conclusion}

As the main objective of the study is to examine the application of competitor accounting in the four leading joint venture banks the study find out that there is no such practice of competitor accounting. Those organizations and their staff even managerial level don't know about the terminology competitor accounting. When researcher try to analyze the effect of various component of competitor accounting with financial performance of those banks by developing hypothesis, they all show insignificant effect only that means research hypothesis is not accepted.

These four joint venture banks do not have any threats of new entrants but of course there is high competition among the joint venture banks. All other competitive forces of industry have negative effects on financial performance of organization.

The study concludes that NABIL is relatively healthier than other banks in terms of greater financial parameter. Whereas SCBNL is relatively stable in all the financial parameter whether there is recession or boom. Other two banks are also doing well but they are not seems as a leader of the industry.

This result is somewhat consistent with the Kosovo competition authority (2011) that strength of the banks is in the deposit and loan market where there is high competition. They preserve a large profit margin compared to interest cost with aggressiveness in the market. Expansion of geographical presence as well as deposit and loan product growth and development will occur in banks like NABIL.

According to theory of competitor accounting relative performance of joint venture banks largely depends on the component of competitor accounting. But from the above analysis we can say that relative performance of Nepalese joint venture banks will not depend on component of competitor accounting. In spite of not having any competitor analysis system as well as not applying any competitor accounting their relative performance is quite good. 


\section{References}

Anderson S. \& Guilding C. (2006),"Competitor-focused accounting applied to a hotel context”, International Journal of Contemporary Hospitality Management, Vol.18 Issue: 3 pp. $206-218$

Bettis R.A. \& Weeks D. (1987), "Financial returns and strategic interaction: the case of instant photograph", Strategic Management Journal, pg. 549

D’ Aveni R.A. (1994), “Top managerial prestige and organizational bankruptcy”, Organization Science, I: 121-142

Guilding, C., Cravens K.S. \&Tayles G. (2000), “An International Comparison of Strategic Management Accounting Practices", Management Accounting Research, 11(1): 113- 135.

Heinen, C., \&Hoffjan, A. (2005), "The strategic relevancy of competitor cost assessment - An empirical study of competitor accounting", Journal of Applied Management Accounting Research, 3(5), 17 - 34

Jarvenpaa, M. (1998), "Management Accounting and strategy. Functional and Institutional perspectives; a case study", Proceedings, Asia Pacific Interdisciplinary Research in Accounting Conference, Osaka, Japan.

Kayastha, R. K. (2010), “A survey on strategic competitive position of Nepalese banking industries", Journal of Management Public Youth College, 3(1), 19 - 25

Kosovo C. A. (2011). Analysis of monitoring the competition in the banking sector in Kosovo, Published by Kosovo Competition Authority.

Kotler, P. (1988). Marketing Management: Analysis, Planning, Implementation and Control, NJ: Prentice Hall Publishing Company. Sixth Edition. Englewood Cliffs.

MacMillan, I. C., McCaffery, M.L., \& van Wijk, G (1985), “Competitors' responses to easily imitated new products: Exploring commercial banking product introductions", Strategic Management Journal, 6: 75-86.

Murthy, B. (1994). Measurement of the strategy construct in the lodging industry, and the strategy performance relationship, Retrieved from Proquest Digital Dissertations. (AAT NR 20145) 
Ndwiga N. M. (2011). The role of management accounting in creating and sustaining competitive advantage: a case study of equity bank, Kenya; Master degree thesis submitted to University of South Africa

Porac, J.F. \& Thomas, H. (1990), "Taxonomic mental models in competitor definition", Academy of Management Review, 15: 224-240.

Porter, M. E. (1980). Competitive strategy: techniques for analyzing industries and competitors. New York: The Free Press.

Smith, K. G., Grimm, C. \& Gannon, M (1992). Dynamics of competitive strategy. London, Sage Publications.

Smith, K. L. (2008),'Strategic management accounting: how far have we come in 25 years?",Accounting, Auditing \& Accountability Journal, Vol. 21 Iss: 2 pp. 204 - 228

Thapa, M. (2010), "Competitive Strategy and performance of the Nepalese Banking Industry", Journal of Management Public Youth College, 3(1), 8 - 18

Vechalekar, N. M. (2010), "Strategic Management Accounting - A Tool for Competitive Advantage", Working paper presented in PGP, IndSearch, Pune.

Official Publication and Relevant Studies

Annual Report of SCBNL from 2007/08 to 2011/12

Annual Report of NABIL from 2007/08 to 2011/12

Annual Report of HBL from 2007/08 to 2011/12

Annual Report of EBL from 2007/08 to 2011/12

Annual Bank Supervision Report of NRB

www.standardchartered.com.np;

www.nabilbank.com;

www.everestbankltd.com;

www.himalayanbank.com

www.nabilbank.com 